\title{
PENGEMBANGAN KARIER BERDASARKAN IDENTITAS DAN ASPIRASI KARIER SANTRI (Pendampingan Bimbingan Karier di Pondok Pesantren Al-Kautsar Pamekasan)
}

\author{
${ }^{1}$ Imam Hanafi, ${ }^{2}$ Ishlakhatus Sa'idah, ${ }^{3}$ Diana Vidya Fakhriyani \\ Institut Agama Islam Negeri Madura \\ 1'rafirama140117@gmail.com, ${ }^{2}$ ishlakhatus@iainmadura.ac.id ${ }^{2}$ \\ 3dianavidya@iainmadura.ac.id
}

\begin{abstract}
Career planning is an essential aspect of individual career development. Skills in making career decisions are the main goals of career planning that every individual must take. Furthermore, career decisions taken by individuals cannot be separated from considerations of self-identity and social, which are a source of value and a place where various things are available individuals can use that for their development. In fact, not all individuals are capable of planning a career. Including the final year students at the Al-Kautsar Pamekasan Islamic Boarding School. The ability of the final year students to prepare for their careers is still low. This can be seen from the various problems that have arisen in relation to the choice of the type of further study, the choice of a job plan, and those related to the unpreparedness of high school graduates to enter further education. Therefore, it is necessary to make efforts to assist students in planning their future careers, one of which is through career guidance services packaged in Community Service. In the implementation of these activities, participants seemed enthusiastic about participating in activities that were marked by actively discussing career planning. The continuity of the implementation of this activity, namely ongoing assistance and consultation.
\end{abstract}

Keywords: Guidance, Career Guidance, Santri

\begin{abstract}
Abstrak
Perencanaan karier merupakan salah satu aspek yang penting dalam perkembangan karier individu. Kecakapan dalam mengambil keputusan karier merupakan tujuan utama dari perencanaan karier yang harus ditempuh oleh setiap individu. Selanjutnya, keputusan karier yang diambil individu tidak lepas dari pertimbangan identitas diri dan sosial yang merupakan sumber nilai dan tempat tersedianya berbagai hal yang dapat dimanfaatkan oleh individu bagi pengembangan dirinya. Faktanya, tidak semua individu mampu dalam merencanakan karier. Termasuk, pada santri tingkat akhir di Pondok Pesantren AIKautsar Pamekasan. Kemampuan santri tingkat akhir dalam mempersiapkan kariernya masih rendah. Hal ini tampak dari berbagai masalah yang muncul baik yang berkaitan dengan pemilihan jenis studi lanjutan, pemilihan rencana pekerjaan maupun yang berkaitan dengan ketidaksiapan para lulusan SMA dalam memasuki pendidikan lanjutan. Maka dari itu, perlu adanya upaya untuk membantu santri
\end{abstract}


dalam merencanakan karier masa depannya, salah satunya yaitu melalui layanan bimbingan karier yang dikemas dalam Pengabdian Kepada Masyarakat. Dalam pelaksanaan kegiatan tersebut, peserta terlihat antusias mengikuti kegiatan yang ditandai dengan aktif berdiskusi tentang perencanaan kariernya. Keberlanjutan pelaksanaan kegiatan ini, yaitu dilakukan pendampingan dan konsultasi secara berkelanjutan.

Kata Kunci: Bimbingan, Bimbingan Karir, Santri

\section{Article Info:}

https://doi.org/10.19105/pjce.v3i1.4341

Received 10 June 2021; Received in revised form 25 June 2021; Accepted 30 June 2021 2684-9615/ @2021 Perdikan: Journal of Community Engagement. This is an open access article under the CC BY-NC 4.0 license (https://creativecommons.org/licenses/by-nc/4.0/)

\section{Pendahuluan}

Bimbingan karier merupakan proses membantu individu dalam memahami dan menerima diri sendiri dan yang kedua membantu memahami sekaligus menyesuaikan diri dengan dunia kerja nyata (Herr \& Cramer, 1984). Bimbingan karier merupakan upaya bantuan terhadap individu agar dapat mengenal dan memahami dirinya, mengenal dunia kerjanya, mengembangkan masa depannya sesuai dengan bentuk kehidupannya yang diharapkan. Sehingga, layanan bimbingan karier dimaksudkan agar individu mampu menentukan aspirasi karier dan mengambil keputusan karier secara tepat dan bertanggung jawab atas keputusan yang diambilnya sehingga mereka mampu mewujudkan dirinya secara bermakna. Selain itu, layanan bimbingan karier juga dimaksudkan agar individu mampu mempersiapkan diri dalam perkembangan kariernya.

Dalam perkembangan karier, santri tingkat akhir (SMA) berada pada tahap eksplorasi. Adapun tugas perkembangan karier pada tahap eksplorasi karier antara lain mengenal keterampilan, membuat keputusan karier dan memperoleh informasi yang relevan untuk membuat keputusan karier, menyadari minat dan kemampuan serta dapat menghubungkannya dengan kesempatan kerja, mengidentifikasi bidang dan pekerjaan yang cocok dengan minat dan kemampuan (Supriatna \& Mamat, 2009). Maka dari itu, perlu adanya upaya untuk membantu santri dalam merencanakan karier masa depannya, salah satunya yaitu melalui layanan bimbingan karier.

Di lapangan, kemampuan santri tingkat akhir dalam mempersiapkan kariernya masih rendah. Hal ini tampak dari berbagai masalah yang muncul baik yang berkaitan dengan pemilihan jenis studi lanjutan, pemilihan rencana pekerjaan maupun yang berkaitan dengan ketidaksiapan para lulusan SMA dalam memasuki pendidikan lanjutan.

Keresahan ini memberikan isyarat bagi dunia pendidikan (terutama sekolah menengah) untuk mengembangkan santri dalam merencanakan kariernya baiknya melalui kegiatan intruksional maupun kegiatan bimbingan dan konseling. Bimbingan karier bukan hanya sekedar memberikan respon 
kepada masalah-masalah yang muncul, akan tetapi juga membantu memperoleh pengetahuan, sikap dan keterampilan yang diperlukan dalam pekerjaan. Bimbingan karier menitikberatkan pada perencanaan kehidupan individu dengan mempertimbangakan identitas diri dan sosial agar ia mampu mengoptimalkan sisi positifnya dan menekan sisi negatifnya.

Di era milenial saat ini tidak sedikit kasus yang dimuat di berbagai surat kabar bahwa banyak diantara lulusan SMA mengalami kegagalan dalam mempersiapkan mental dan kepribadian ketika memasuki dunia kerja. Bahkan, daya juang generasi masa kini ini bisa dikatakan relatif rendah. Hasil wawancara yang pernah dilakukan peneliti pada beberapa individu yang menjadi sampel penelitian diketahui bahwa pada umumnya mereka (santri kelas XII) masih merasa bingung akan memilih karier lanjutan pasca SMA. Selain itu, pemberian layanan bimbingan karier yang diterima santri dirasa belum optimal. Hal ini ditandai dengan masih minimnya pengetahuan santri mengenai informasi karier, baik yang berhubungan dengan dunia kerja maupun informasi mengenai jurusan yang ada di perguruan tinggi.

Kesulitan-kesulitan untuk mengambil keputusan karier akan dapat dihindari jika santri memiliki sejumlah informasi yang memadai tentang halhal yang berhubungan dengan dunia kariernya. Oleh karena itu, seyogyanya mereka mendapatkan bimbingan guna memperoleh pemahaman yang memadai tentang berbagai kondisi dan karakteristik dirinya, baik dari sisi identitas diri dan sosial maupun aspirasi karier yang ada dalam dirinya. Pemahaman identitas diri dan sosial akan membawa santri memahami kelebihan dan kekurangan dirinya, kondisi sosio-kultural, dsb. Sedangkan sisi aspirasi karier akan membawa santri memahami halhal yang melandasi pemilihan karier tersebut, persyaratan, jenis dan prospek pekerjaan serta hal lain yang berhubungan dengan cita-citanya. Pemberian bimbingan karier sangat diperlukan agar potensi santri dapat dikembangkan secara optimal. Selain itu, program bimbingan dapat diarahkan untuk menjaga terjadinya keseimbangan dan keserasian dalam perkembangan intelektual, emosional dan sosial.

Bukan hanya itu, program bimbingan karier juga diharapkan dapat mencegah dan mengatasi potensi-potensi negatif seperti santri mudah frustasi karena adanya tekanan dan tuntutan berprestasi, santri menjadi terasing atau agresif dalam menentukan kariernya. Program bimbingan karier bertujuan untuk membantu santri dalam merencakan karier di masa mendatang. Melalui program bimbingan karier diharapkan karier yang dipilih santri sesuai dengan identitas diri dan sosial serta aspirasi kariernya. Jika individu memperoleh karier yang tepat, maka hidup individu tersebut akan bahagia. Sedangkan kebahagiaan adalah tujuan hidup semua orang. Oleh karena itu, urgensi bimbingan karier sangat tinggi karena tak terpisahkan dari tugas pendidikan itu sendiri.

\section{Metode}

Pelaksanaan Pengabdian Kepada Masyarakat ini dilaksanakan dengan beberapa metode, yaitu metode ceramah \& metode PIJAR. Ceramah 
dengan maksud memberikan bimbingan karier dalam rangka mengembangkan pemahaman, sikap dan keterampilan membuat keputusan karier berdasarkan pertimbangan identitas diri dan sosial serta aspirasi karier masing-masing individu. Dengan kata lain, tujuan yang ingin dicapai dalam pengabdian ini yaitu dapat memberikan informasi, pemahaman, dan keterampilan pada santri dalam perencanaan karir masa depannya.

Metode "PIJAR" yaitu Pahami diri, Identifikasi kebutuhan dan harapan, Jelaskan dan evaluasi perilaku saat ini, Arahkan rencana dan solusi dan Realisasi rencana. Model ini dikembangkan dari konsep dasar Choice Theory and Reality Therapy. Terapi ini berfokus pada pengembangan perilaku positif dan pengembangan tanggung jawab (Burdenski \& Wubbolding, 2011). Teori ini dipilih karena sesuai dengan permasalahan santri di lokasi sasaran pengabdian masyarakat. Pendekatan ini dimodifikasi sesuai dengan karakteristik santri. Oleh karena itu, teknik-teknik yang digunakan disesuaikan dengan perkembangan santri, salah satunya melalui menggambar dalam mengungkapkan kondisi diri santri (Davis \& S., 2011).

Dalam realisasinya dilakukan kegiatan-kegiatan penerapan tahapan Model Pijar dengan melakukan bimbingan dan pembelajaran aktif melalui metode ekspositori persuasif, metode dialog interaktif, metode diskusi kelompok, dan metode permainan dan penugasan.

\section{Hasil dan Pembahasan}

Kegiatan pengabdian kepada masyarakat ini dilaksanakan pada 20 dan 23 November 2020 di Ruang Pertemuan Pondok Pesantren Al-Kautsar Pamekasan. Kegiatan yang diikuti oleh 26 orang santri ini, bertujuan untuk memberikan bimbingan karier bagi santri tingkat akhir dalam rangka merencanakan dan memutuskan pilihan kariernya sesuai dengan identitas dan aspirasi karier masing-masing. Dalam pelaksanaan kegiatan tersebut, peserta terlihat antusias mengikuti kegiatan yang ditandai dengan aktif berdiskusi tentang perencanaan kariernya (Kamus Besar Bahasa Indonesia. [Online]., n.d.).

Pada materi pertama, peserta diarahkan untuk mengenali diri dan juga potensi yang ada pada diri masing-masing santri. Penyampain materi menggunakan media presentasi berupa power point dengan menggunakan model pijar. Adapun metode yang digunakan antara lain permainan, diskusi, ceramah dan pemberian tugas.

Pada materi kedua, peserta diarahkan untuk membuat perencanaan karier sesuai dengan temuan potensi diri masing-masing santri. Dan materi yang terakhir yakni pengambilan keputusan karier yang bertujuan untuk memberikan keterampilan pada santri untuk mampu memilih karier impian mereka. Selanjutnya, pemberian motivasi yang berkaitan dengan perencanaan karier santri, refleksi kegiatan, sekaligus penutup. 
Setelah pelaksanaan kegiatan pengabdian kepada masyarakat selesai, dilakukan pendampingan dan konsultasi secara berkelanjutan. Pendampingan dan konsultasi dilakukan melalui sosial media Whatsapp. Selanjutnya dilakukan evaluasi dan refleksi kegiatan agar kegiatan ini tetap berkelanjutan.

Bimbingan karier adalah bimbingan dalam mempersiapkan diri menghadapi dunia pekerjaan, dalam memilih lapangan pekerjaan atau jabatan/profesi tertentu serta membekali diri supaya siap memangku jabatan itu, dan dalam menyesuaikan diri dengan berbagai tuntutan dari lapangan perkerjaan yang telah dimasuki (Winkel \& Hastuti, 2005). Berdasarkan pengertian tersebut, bimbingan karier bisa bermakna sebagai suatu bantuan yang diberikan pembimbing kepada individu yang dibimbing dalam menghadapi dan memecahkan masalah karier. Begitu pula, kegiatan Pengabdian Kepada Masyarakat di Pondok Pesantren Al-Kautsar Pamekasan, yakni memberikan layanan bimbingan karier pada santri tingkat akhir.

Tujuan bimbingan karier adalah untuk membantu individu memperoleh kompetensi yang diperlukan hidupnya dan mengembangkan karier yang dipilihnya secara optimal (Surya \& Moh., 1988). Latar belakang dilaksanakannya kegiatan Pengabdian Kepada Masyarakat, yakni Layanan bimbingan karier ini adalah agar 1) santri memahami pertimbangan identitas diri dan sosial dalam pemilihan karier, 2) santri memiliki alternatif pilihan karier berdasarkan aspirasi kariernya, serta 3) adanya bimbingan dalam membuat keputusan karier santri (Gregor \& O'Brien, 2016).

Selanjutnya, kegiatan pengabdian kepada masyarakat ini pada hakekatnya adalah usaha untuk memberikan layanan bimbingan karier pada santri agar mampu merencanakan dan memutuskan pilihan kariernya sesuai dengan identitas dan aspirasi kariernya. Hal ini menjadi penting melihat kondisi santri yang telah berada pada tingkat akhir namun masih mengalami kebingungan dalam menentukan arah karier pasca lulus dari bangku SMA (Hornby, 2000). Kegiatan ini merupakan kegiatan pembimbingan yang berkelanjutan sesuai dengan kesepakatan yang tertuang dalam butir-butir piagam Kerjasama antara Yayasan Al-Kautsar dengan Program studi Bimbingan dan Konseling Pendidikan Islam (BKPI) IAIN Madura dalam ranah pembinaan kualitas peserta didik.

Pada pelaksanaannya, kegiatan Pengabdian Kepada Masyarakat dengan tema "Pengembangan karier berdasarkan identitas dan aspirasi karier santri (bimbingan karier di Pondok Pesantren Al-Kautsar) " dapat dilaksanakan dengan baik (Gunarsa \& Singgih, 2003). Hal ini tentu disebabkan adanya beberapa faktor pendukung, diantaranya: 
1. Adanya dukungan dari ketua yayasan Al-Kautsar dalam penyelenggaraan kegiatan Pengabdian Kepada Masyarakat.

2. Fasilitas dan kemudahan yang diberikan oleh Pengasuh Pondok Pesantren Al-Kautsar.

3. Para santri tingkat akhir di Pondok Pesantren Al-Kautsar sangat antusias dalam mengikuti kegiatan tersebut sampai selesai dibuktikan dengan daftar kehadiran mereka mencapai $100 \%$ sampai kegiatan selesai.

4. Sarana dan prasarana yang disediakan oleh yayasan Al-Kautsar sangat menunjang kegiatan.

5. Mudahnya pengurusan administrasi kegiatan (Osipow \& H., 1983).

Di samping adanya faktor pendukung tersebut, pelaksanaan kegiatan ini juga mengalami kendala, yaitu terdapat beberapa santri yang menjadi pengurus tidak bisa fokus mengikuti kegiatan secara penuh dikarenakan memiliki tugas lain pada saat yang sama dengan kegiatan Pengabdian Kepada Masyarakat ini.

Namun demikian, kegiatan pengabdian dalam bentuk pemberian layanan bimbingan karier ini terlaksana dengan baik bahkan para peserta terlihat antusias dan mengharapkan kegiatan tersebut diadakan kembali pada masa yang akan dating (Santrock \& W., 2002). Bukan hanya peserta, pegurus yayasan juga mengharapkan adanya kegiatan serupa yang berkelanjutan sehingga semakin dapat meningkatkan mutu lulusan.

\section{Kesimpulan dan Saran}

Kesimpulan dalam pelaksanaan Pengabdian Kepada Masyarakat dengan tema "Pengembangan karier berdasarkan identitas dan aspirasi karier santri (bimbingan karier di Pondok Pesantren Al-Kautsar)", yaitu:

a. Melalui kegiatan Pengabdian Kepada Masyarakat ini, membantu santri dalam memiliki pemahaman yang utuh atas potensi diri yang ada pada diri masing-masing.

b. Melalui kegiatan Pengabdian Kepada Masyarakat, yakni pemberian layanan bimbingan karier ini, menumbuhkan kesadaran santri akan pentingnya merencanakan karier masa depan pada usia emas.

c. Pemberian layanan bimbingan karier pada santri tingkat akhir memungkinkan santri memperoleh berbagai informasi yang cukup dalam rangka orientasi karier masa depan.

d. Pemberian layanan bimbingan karier pada santri tingkat akhir dirasa sangat penting karena juga bertujuan membantu pemetaan arah karier pasca lulus SMA.

e. Terlaksananya kegiatan ini, memungkinkan adanya tenaga bimbingan dan konseling yang sebelumnya belum ada pada lembaga tersebut, karena pentingnya pemberian layanan secara berkelanjutan sehingga selanjutnya layanan bimbinga karier dapat berjalan secara optimal (Sa'idah, 2018).

Adapun saran yang dapat dijadikan pertimbangan, terutama bagi lembaga pendidikan di Pondok Pesantren, yaitu: 
a. Pengadaan tenaga bimbingan dan konseling pada lembaga agar pemberian layanan bimbingan karier dalam rangka persiapan karier masa depan santri dapat dilaksanakan secara rutin.

b. Perlu adanya pengembangan media layanan informasi yang telah disesuaikan dengan situasi dan kondisi pondok sehingga santri tetap mendapatkan informasi pilihan karier meskipun tidak bisa mengakses secara mandiri melalui gadget atau media elektronik lainnya.

Perlu adanya layanan bimbingan dan konseling baik dari bidang pribadi, sosial, belajar maupun karier guna mengoptimalkan perkembangan santri agar sesuai dengan tahapan perkembangan yang seharusnya. Jika masih belum memungkinkan merekrut tenaga bimbingan dan konseling, maka bisa mengadakan kerjasama atau sejenisnya kepada lembaga tertentu untuk membantu pengadaan layanan bimbingan dan konseling di pondok (Erikson \& Erick, 1989).

\section{Referensi}

Burdenski, T., \& Wubbolding, R. (2011). Extending Reality Therapy with Focusing: A Humanistic Road for the Choice Theory Total Behavior Car. International Journal of Choice Theory and Reality Therapy, 31(1), 14-30.

Davis, \& S., E. (2011). Drawing Out the Child: Combining the WDEP Method with Drawing to Work with Children. International Journal of Choice Theory and Reality Therapy, 31(1), 48-52.

Erikson, \& Erick, H. (1989). Identitas dan Siklus Hidup Manusia; Bunga Rampai 1. Penerjemah. PT. Gramedia.

Gregor, M. A., \& O'Brien, K. M. (2016). Understanding Career Aspirations Among Young Women: Improving Instrumentation. Journal of Career Assessment, 24(3), 559-572., 24(3), 559-572.

Gunarsa, \& Singgih, D. (2003). Psikologi Untuk Keluarga. Gunung Mulia.

Herr, E., \& Cramer, S. (1984). Career Guidance and Counseling Through the Life Span, Boston: Little Brown Company.

Hornby, A. S. (2000). Oxford Advenced Learner's Dictionary of Current English. Oxford Univ. Press.

Kamus Besar Bahasa Indonesia. [Online]. (n.d.). kbbi.kemdikbud.go.id.

Osipow, \& H., S. (1983). Theories of Career Development. The Ohio State University.

Sa'idah, I. (2018). Aspirasi Karier Generasi Milenial (Studi Fenomenologi Di Kawasan Industri). Doctoral dissertation, Universitas Negeri Malang.

Santrock, \& W., J. (2002). Life Span Development; Perkembangan Masa Hidup. Penerjemah : Jakarta : Penerbit Erlangga.

Supriatna, \& Mamat. (2009). Bimbingan Karir di SMK. Bandung: UPI.

Surya, \& Moh. (1988). Dasar-Dasar Konseling Pendidikan (Konsep dan Teori). Yogyakarta: Kota Kembang.

Winkel, W. S., \& Hastuti, M. S. (2005). Bimbingan dan konseling di institusi pendidikan. Yogyakarta: Media Abadi. 